Check for updates

Cite this: RSC Adv., 2019, 9, 5925

Received 14th December 2018 Accepted 11th February 2019

DOI: $10.1039 / c 8 r a 10269 d$

rsc.li/rsc-advances

\section{ACE-inhibitory and antioxidant peptides from coconut cake albumin hydrolysates: purification, identification and synthesis $\uparrow$}

\begin{abstract}
Yajun Zheng, (D) $\ddagger^{* a b}$ Yan Li $\ddagger^{\text {ab }}$ and Guifeng Li
Coconut cake albumin was hydrolysed by sequential digestion with alcalase, flavourzyme, pepsin and trypsin to purify bioactive peptides with ACE-inhibitory and antioxidant activities. Following fractionation with sequential ultrafiltration, Sephadex gel chromatography and RP-HPLC, three novel peptides KAQYPYV, KIIIYN and KILIYG were identified. KAQYPYV, KIIIYN and KILIYG provided an IC 50 value of $37.06 \mu M, 58.72$ $\mu \mathrm{M}$ and $53.31 \mu \mathrm{M}$ on ACE-inhibitory activity, respectively. For hydroxyl radical scavenging activity, KAQYPYV, KIIIYN and KILIYG demonstrated an $I_{50}$ value of $70.84 \mu \mathrm{M}, 77.62 \mu \mathrm{M}$ and $95.23 \mu \mathrm{M}$, respectively. All the three peptides exhibited a mixed modality of noncompetitive and uncompetitive inhibition on ACE and KAQYPYV showed good stability against gastrointestinal enzymes digestion. Moreover, these peptides could effectively lower intracellular endothelin-1 content without significant cytotoxicity, and protected vascular endothelial cells from reactive oxygen species mediated damage. Furthermore, KAQYPYV, KIIIYN and KILIYG also demonstrated high ion chelating ability $(62.13 \% \pm 4.21 \%, 64.66 \% \pm 5.51 \%$ and $69.82 \% \pm 7.24 \%$ at $0.1 \mathrm{mg} \mathrm{mL}^{-1}$, respectively) and considerable superoxide radical scavenging activity $(39.30 \% \pm 2.72 \%$, $46.79 \% \pm 1.70 \%$ and $51.16 \% \pm 3.23 \%$ at $1.0 \mathrm{mg} \mathrm{mL}^{-1}$, respectively). These results indicate that coconut cake albumin is a potential source of bioactive peptides possessing ACE-inhibitory and antioxidant activities.
\end{abstract}

\section{Introduction}

It has been demonstrated that hypertension is a significant risk factor for cardiovascular diseases and threatens the health of one fourth of the adults in the world. ${ }^{\mathbf{1 , 2}}$ Angiotensin-I converting enzyme (ACE) makes a positive contribution to hypertension since it can catalyze the conversion of inactive angiotensin-I into angiotensin-II (a potent vasoconstrictor) and deactivate bradykinin (a potent vasodilator) in the renin-angiotensin system, leading to increase in blood pressure. ${ }^{3}$ Thus, hypertension is commonly treated by drugs such as captopril and enalapril, which can lower the blood pressure by inhibiting ACE activity. Except for the renin-angiotensin system, the regulation of blood pressure is regulated by other complex systems, involving the sympathetic nervous system, the endothelin system, kidney and fluid balance mechanisms and the nitric oxide system. ${ }^{4}$ In the endothelin system, the endothelin converting enzyme cleaves the biologically inactive intermediate termed big endothelin-1 to form endothelin-1 (ET-1) which has powerful vasoconstrictor and

${ }^{a}$ College of Food Science, Shanxi Normal University, Linfen, 041004, China. E-mail: zyj_coconut@163.com; Fax: +86-0357-2051482; Tel: +86-13976563642

${ }^{b}$ College of Life Sciences and Food Engineering of Hebei Engineering University, Handan 056038, China

$\dagger$ Electronic supplementary information (ESI) available. See DOI: 10.1039/c8ra10269d

\$ The two authors contribute equally to this work and they are co-first author. pressor properties, cause the rise of blood pressure. ${ }^{5}$ Moreover, increasing epidemiological evidence demonstrated that oxidative stress and associated oxidative damage were mediators in hypertension and other chronic diseases like arthritis, diabetes and neurodegenerative diseases. ${ }^{6}$ Oxidative stress also can disturb the balance between oxidants and antioxidants in cells which is very important to human's health. ${ }^{7}$

More studies demonstrated that the control and improvement of diet could handle both hypertension and oxidative stress, which is helpful to prevent the occurrence of hypertension and other cardiovascular diseases. Therefore development of nutraceuticals or functional foods would be a low-cost alternative to conventional synthetic therapeutics which always has possible harmful side effects. ${ }^{4}$ In the recent years, ACE-inhibitory and/or antioxidant peptides obtained from food natural sources receiving an increasing interest in the world. Many ACEinhibitory and/or antioxidant peptides has been purification and identified from food-derived proteins, including animal proteins, plant proteins and marine proteins. ${ }^{7-17}$ These bioactive peptides are usually short protein sequences (2-20 amino acids long), and some of them can reveal other functions like antimicrobial, beyond antioxidative and ACE-inhibitory activity. ${ }^{9}$

Albumin is commonly known as water-soluble protein and makes a significant contribution to the human diet. Some albumins such as lactoalbumin, ovalbumin and wheat albumin can exert physiological hormone-like effects on humans beyond their nutritional value. ${ }^{3,18}$ Coconut cake is a byproduct of the 
coconut oil industry, contains about $10 \%$ to $16 \%$ of protein, in which albumin and globulin are the predominant fractions, accounting for about $31 \%$ and $60 \%$, respectively. ${ }^{19}$ Previous study found that coconut albumin could effectively protect DNA against oxidative damage and exhibited considerable superoxide radical scavenging activity (14.99\%), reducing power $(0.122 \pm 0.010)$ and ACE inhibition activity $(12.67 \pm 3.08 \%){ }^{20}$ indicating that bioactivity peptides with antioxidant and potential antihypertensive effect may be isolated from it. Although three antimicrobial peptides (Cn-AMP1, Cn-AMP2 and Cn-AMP3) were identified from green coconut water, ${ }^{21}$ and several ACE-inhibitory and antioxidant peptides (Pro-Gln-PheTyr-Trp, Val-Val-Leu-Tyr-Arg and Arg-Pro-Glu-Ile-Val) were identified from coconut cake globulin hydrolysates. ${ }^{22,23}$ There is no study on antioxidant and ACE-inhibitory peptides derived from coconut cake albumin. The annual production of coconut cake is about 63 million tons in the world, ${ }^{24}$ meaning that a large amount of albumin could be produced. If peptides with high antihypertensive or antioxidant activity could be obtained from it, the usage of coconut cake will be expanded and remarkable economic benefits may be achieved. Therefore, the current study aimed at the isolation, identification, synthesis and characterization of ACE-inhibitory and/or antioxidative peptides from coconut cake albumin.

\section{Materials and methods}

\subsection{Materials and reagents}

Coconut cake was obtained from South Coconut Food Processing Co., China. Flavourzyme $\left(5 \times 10^{4} \mathrm{U} \mathrm{g}^{-1}\right)$, alcalase $(1 \times$ $\left.10^{5} \mathrm{U} \mathrm{g}^{-1}\right)$, pepsin $\left(1 \times 10^{5} \mathrm{U} \mathrm{g}^{-1}\right)$ and trypsin $\left(1 \times 10^{5} \mathrm{U} \mathrm{g}^{-1}\right)$ were purchased from Shanghai Biotech. Co., Ltd. (China). ACE (from rabbit lung) and N-Hippuryl-His-Leu hydrate (HHL) were purchased from Sigma Co., USA. The human endothelial cell line (EA.hy926) was from the Type Culture Collection of the Chinese Academy of Sciences, Shanghai, China. Dulbecco's modified Eagle's medium (DMEM) and fetal bovine serum (FBS) were purchased from Sijiqing Biological Co., China. Human endothelin-1 (ET-1) Elisa kit was purchased from Ruiqi Biological Co. Ltd., China. GSH (glutathione), ferrozine and 2Deoxy-D-ribose were purchased from Yeyuan Biotech. Co., Ltd., Shanghai, China. MTT (3-(4,5-dimethylthiazol-2-yl)-2,5diphenyltetrazolium bromide) and other chemicals and reagents were of analytical grade. Three isolated peptides (KAQYPYV, KIIIYN and KILIYG) were synthesized using the method of the solid phase procedure described by Zhang et al. ${ }^{25}$

\subsection{Extraction of coconut cake albumin (CCA)}

CCA was prepared according to the method described by Kwon et $a{ }^{26}$ Coconut cake was defatted three times with $n$-hexane $\left(1: 10, \mathrm{~g} \mathrm{~mL}^{-1}\right)$ and dried, ground and passed through a sieve of $0.2 \mathrm{~mm}$ mesh. The obtained defatted coconut cake were mixed with distilled water $\left(1: 15, \mathrm{~g} \mathrm{~mL}^{-1}\right)$, stirred at $4{ }^{\circ} \mathrm{C}$ for $1 \mathrm{~h}$ and then the mixture was filtrated. The filtrate was collected and the residue was resuspended in distilled water and stirred at $4{ }^{\circ} \mathrm{C}$ for $1 \mathrm{~h}$. This step was repeated in three times. The filtrate was pooled and centrifuged at $10000 \mathrm{~g}$ for $30 \mathrm{~min}$, the supernatant was collected, dialyzed against distilled water for $24 \mathrm{~h}$ at $4{ }^{\circ} \mathrm{C}$. Then the dialyzation was centrifuged at $10000 \mathrm{~g}$ for $30 \mathrm{~min}$, and the supernatant was collected and lyophilized. Then CCA was obtained and stored at $-20{ }^{\circ} \mathrm{C}$.

\subsection{Hydrolysis of coconut cake albumin}

The enzymatic hydrolysis of CCA was performed following the method reported by Zheng et al. ${ }^{27}$ The CCA solution $(5 \mathrm{~g} / 100 \mathrm{~mL})$ was transferred into polyethylene bags, sealed under vacuum and subjected to high pressure treatment using a HPP-L3 high-pressure apparatus (Tianjin HuaTaiSenMiao Biotechnology Co. Ltd., China) at $400 \mathrm{MPa}, 35^{\circ} \mathrm{C}$ for $15 \mathrm{~min}$. Then the CCA solution was separately hydrolyzed by alcalase, flavourzyme, pepsin, trypsin and a mixture of these four enzymes. The reaction conditions of each enzyme and hydrolysis degree (DH), ACE-inhibitory and antioxidant activity of coconut cake albumin hydrolysates (CCAH) were shown in Table 1. Results showed that when CCA was sequentially hydrolyzed by alcalase, flavourzyme, pepsin and trypsin, CCAH demonstrated the highest ACE-inhibitory and antioxidant activity. Thus, these four enzymes were chose to hydrolyze CCA in the following sequence: alcalase, flavourzyme, pepsin and trypsin. Moreover, the use of pepsin and trypsin was to improve the stability of peptides from coconut cake albumin against the gastrointestinal enzymes digestion. At the end of the hydrolysis, the reaction solutions were incubated in $100{ }^{\circ} \mathrm{C}$ for 5 min to inactivate the enzyme, and then centrifuged at $10000 \mathrm{~g}, 4{ }^{\circ} \mathrm{C}$ for $20 \mathrm{~min}$. The supernatants were collected and lyophilized to obtain CCAH. The degree of hydrolysis (DH), ACE-inhibitory ability and hydroxyl radical $(\cdot \mathrm{OH})$ scavenging activity of coconut cake albumin hydrolysis (CCAH) were determined using the methods of Adler-Nissen, Jimsheena \& Gowda and the 2-deoxyribose oxidation method, ${ }^{8,28,29}$ respectively.

\subsection{Degree of hydrolysis (DH)}

The DH of CCAH was analyzed using the trinitrobenzenesulfonic acid (TNBS) method. ${ }^{28}$ Briefly, $250 \mu \mathrm{L}$ of coconut cake albumin hydrolysate solution was mixed with $2.0 \mathrm{~mL}$ of phosphate buffer (0.2 M, pH 8.2) and $2.0 \mathrm{~mL}$ of TNBS solution $\left(1 \mathrm{mg} \mathrm{mL}^{-1}\right)$. The mixture was incubated at $50{ }^{\circ} \mathrm{C}$ for $60 \mathrm{~min}$ in dark, and then $4 \mathrm{~mL}$ of $0.1 \mathrm{M} \mathrm{HCl}$ was added to terminate the reaction. After cooled at room temperature for $30 \mathrm{~min}$, the absorption was measured at $340 \mathrm{~nm}$ to quantitate free amino nitrogen. L-Leucine $(0-2.0 \mathrm{mM}$, dissolved in 1\% SDS) was used to construct a standard curve. Total amino nitrogen in protein was obtained by acid hydrolysis with $6.0 \mathrm{M} \mathrm{HCl}$ at $110{ }^{\circ} \mathrm{C}$ for $24 \mathrm{~h}$, filtered and neutralized. The $\mathrm{DH}$ was calculated as follows:

$$
\mathrm{DH}(\%)=\left(\mathrm{AN}_{2}-\mathrm{AN}_{1}\right) / \mathrm{N}_{\mathrm{pb}} \times 100
$$

where, $\mathrm{AN}_{2}=$ free amino nitrogen of hydrolysate $\left(\mathrm{mg} \mathrm{g}^{-1}\right), \mathrm{AN}_{1}$ $=$ free amino nitrogen of protein $\left(\mathrm{mg} \mathrm{g}^{-1}\right)$, and $\mathrm{N}_{\mathrm{pb}}=$ total amino nitrogen of the peptide bonds in protein $\left(\mathrm{mg} \mathrm{g}^{-1}\right)$.

\subsection{ACE-inhibitory activity and inhibition pattern}

According to the method of Jimsheena \& Gowda, ${ }^{29} 50 \mu \mathrm{L}$ of sample solution, $50 \mu \mathrm{L}$ of ACE (25 mill units permL) and $150 \mu \mathrm{L}$ 
Table 1 The degree of hydrolysis (DH), ACE inhibition activity and hydroxyl radical $(\cdot \mathrm{OH})$ scavenging activity of coconut cake albumin hydrolysates (CCAH) by different enzymes ${ }^{a}$

\begin{tabular}{|c|c|c|c|}
\hline Alcalase & $20.94 \pm 2.26^{\mathrm{e}}$ & $35.05 \pm 3.67^{\mathrm{e}}$ & $42.56 \pm 2.46^{\mathrm{e}}$ \\
\hline Pepsin & $3.15 \pm 0.61^{g}$ & $9.94 \pm 1.63^{\mathrm{h}}$ & $17.37 \pm 1.09^{\mathrm{h}}$ \\
\hline Trypsin & $10.67 \pm 1.34^{\mathrm{f}}$ & $20.80 \pm 3.08^{\mathrm{g}}$ & $24.02 \pm 1.93^{g}$ \\
\hline Alcalase, flavourzyme, pepsin and trypsin ${ }^{c}$ & $27.62 \pm 3.94^{\mathrm{d}}$ & $48.34 \pm 1.41^{\mathrm{d}}$ & $55.02 \pm 6.28^{\mathrm{d}}$ \\
\hline
\end{tabular}

of $8.3 \mathrm{mM}$ HHL were mixed and incubated at $37^{\circ} \mathrm{C}$ for $60 \mathrm{~min}$, followed by termination of the reaction by adding $250 \mu \mathrm{L}$ of $1 \mathrm{M}$ HCl. Then $1.4 \mathrm{~mL}$ of ethyl acetate was added and the mixture was vortexed for $5 \mathrm{~s}$ and centrifuged at $14100 \mathrm{~g}$ for $5 \mathrm{~min}$. One $\mathrm{mL}$ of the upper organic phase was transferred into a test tube and placed in a vacuum oven at $80{ }^{\circ} \mathrm{C}$ for $1 \mathrm{~h}$. Subsequently, $2 \mathrm{~mL}$ of distilled water was added and the absorbance at $228 \mathrm{~nm}$ was read. The $\mathrm{IC}_{50}$ value was defined as the concentration of inhibitor required to inhibit $50 \%$ of the ACE activity. The inhibition (\%) was calculated as below:

$$
\text { ACE inhibition }(\%)=\left(1-A_{\mathrm{S}} / A_{\mathrm{C}}\right) \times 100
$$

where, $A_{\mathrm{C}}$ was the absorbance of the ACE solution without an inhibitor, $A_{\mathrm{S}}$ was the absorbance of mixture contained samples. Determination of the ACE inhibition pattern was carried out according to the method published by Bush et al. ${ }^{30}$ Different concentrations of ACE-inhibitory peptide (0.1, 0.2, $0.5 \mathrm{mg}$ $\mathrm{mL}^{-1}$ ) were added to each reaction mixture and the enzyme activity was measured with different concentrations of HHL $(0.76,1.52,3.04,3.80$ and $7.60 \mathrm{mM})$. The ACE-inhibitory activity was determined and the kinetics of ACE in the presence of the inhibitor was determined by Lineweaver-Burk plots.

\subsection{Scavenging activity of hydroxyl radical}

Hydroxyl radical $(\cdot \mathrm{OH})$ scavenging activity was assayed using the 2-deoxyribose oxidation method. ${ }^{8} 100 \mu \mathrm{L}$ of CCAH solution was mixed with $1.4 \mathrm{~mL}$ of sodium phosphate buffer $(0.1 \mathrm{M}, \mathrm{pH}$ 7.4), $100 \mu \mathrm{L}$ of $10 \mathrm{mM}$ 2-deoxyribose, $100 \mu \mathrm{L}$ of $10 \mathrm{mM} \mathrm{FeSO} 4$, $100 \mu \mathrm{L}$ of $10 \mathrm{mM}$ ethylenediaminetetra acetic acid (EDTA) and $100 \mu \mathrm{L}$ of $\mathrm{H}_{2} \mathrm{O}_{2}(10 \mathrm{mM})$. After incubation at $37{ }^{\circ} \mathrm{C}$ for $1 \mathrm{~h}$, $1.0 \mathrm{~mL}$ of trichloroacetic acid $\left(28 \mathrm{mg} \mathrm{mL}^{-1}\right)$ and $1.0 \mathrm{~mL}$ of 2 thiobarbituric acid $\left(10 \mathrm{mg} \mathrm{mL}^{-1}\right)$ were added. Then the mixture was kept in boiling water bath for $20 \mathrm{~min}$. After cooled to room temperature, the absorbance of the mixture at $532 \mathrm{~nm}$ was read. The activity was determined using the equation:

$$
\text { - OH scavenging activity }(\%)=\left[1-\left(A_{\mathrm{S}}-A_{\mathrm{B}}\right) / A_{\mathrm{C}}\right] \times 100
$$

where $A_{\mathrm{B}}$ was the absorbance of the blank (distilled water instead of samples), $A_{\mathrm{C}}$ was the absorbance of control (without the addition of 2-deoxyribose oxidation) and $A_{\mathrm{S}}$ was the absorbance of mixture contained samples. $\mathrm{IC}_{50}$ was defined as the concentration of peptide that was required to scavenge $50 \%$ of radical activity.

\subsection{Purification of the bioactivity peptides}

$\mathrm{CCAH}$ was separated by four steps in the following sequence: ultrafiltration, Sephadex G-25 gel chromatography, Sephadex G15 gel chromatography and reversed-phase high performance liquid chromatography (RP-HPLC). Firstly, the CCAH was filtered sequentially using an ultrafiltration unit (Pellicon XL, Millipore, USA) through two ultrafiltration membranes with molecular weight (MW) cut-off of 5 and $3 \mathrm{kDa}$, respectively. Three fractions were obtained: CCAH-I with $\mathrm{MW}>5 \mathrm{kDa}, \mathrm{CCAH}-$ II with MW 3-5 kDa and CCAH-III with MW $<3 \mathrm{kDa}$. The fraction with the highest ACE-inhibitory activity was further separated by a Sephadex G-25 gel filtration column $(\Phi 2.6 \mathrm{~cm} \times 60$ $\mathrm{cm})$ equilibrated with distilled water at $1.0 \mathrm{~mL} \mathrm{~min}^{-1}$. The column was eluted with distilled water and monitored at $220 \mathrm{~nm}$. Fractions were collected, lyophilized and their ACEinhibitory activity and $\cdot \mathrm{OH}$ scavenging activity were measured. The fraction showing the highest ACE-inhibitory activity and/or $\cdot \mathrm{OH}$ scavenging activity was separated by Sephadex G-15 chromatography $(\Phi 1.2 \mathrm{~cm} \times 100 \mathrm{~cm})$ equilibrated with distilled water at $0.8 \mathrm{~mL} \mathrm{~min}^{-1}$. The column was eluted with distilled water and monitored at $220 \mathrm{~nm}$. The fraction showing the highest ACE-inhibitory activity and/or $\cdot \mathrm{OH}$ scavenging activity was separated by RP-HPLC on a Zorbax semipreparative $\mathrm{C}_{18}$ column $(\Phi 9.4 \mathrm{~mm} \times 250 \mathrm{~mm}$, Agilent Technologies, USA), using a linear gradient of acetonitrile containing $0.1 \%$ TFA (5-30\%, in $30 \mathrm{~min}$ ) at a flow rate of $2.5 \mathrm{~mL} \mathrm{~min}^{-1}$. The fraction showing the highest ACE-inhibitory activity and/or $\cdot \mathrm{OH}$ scavenging activity was further isolated on a Zorbax analysis $\mathrm{C}_{18}$ column $(\Phi 4.6 \mathrm{~mm} \times 250 \mathrm{~mm}$, Agilent Technologies, USA) with a linear gradient of acetonitrile containing $0.1 \%$ TFA (5-25\%, in

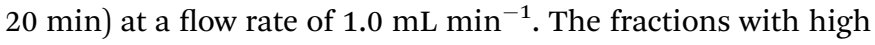
ACE-inhibitory activity and/or antioxidant activity were 
rechromatographed to confirm their purity on the same

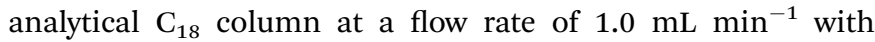
a linear gradient of acetonitrile containing $0.1 \%$ TFA (15-30\%, in $15 \mathrm{~min})$. The fractions with high ACE-inhibitory activity and/ or $\cdot \mathrm{OH}$ scavenging activity were subjected to LC-MS/MS analysis.

\subsection{Molecular mass and amino acid sequence of the purified peptides}

To identify molecular mass and amino acid sequence, the purified fractions from RP-HPLC with highly ACE-inhibitory and antioxidant activity, namely A4e-3 was analyzed by LCMS/MS with a coupled Eksigent Nano LC (Eksigent Technologies, Dublin, CA, USA) and Thermo LTQ linear ion trap mass spectrometer (Thermo Fisher, San Jose, CA, USA). Briefly, acetonitrile $(2 \%, \mathrm{v} / \mathrm{v})$ containing $0.1 \%$ formic acid was used as mobile phase A and acetonitrile $(80 \%, \mathrm{v} / \mathrm{v})$ with $0.1 \%$ formic acid as mobile phase B for Nano-LC separation. Gradient elution was carried out according to the following process: phase B was linearly increased from $5 \%$ to $50 \%$ within $85 \mathrm{~min}$; afterwards, phase B was increased to $95 \%$ within the following $10 \mathrm{~min}$, and then maintained at $95 \%$ for $30 \mathrm{~min}$. Sequence identification of the eluted peptides were analyzed by MS/MS, and the parameters were: spray voltage: $2.2 \mathrm{kV}$, normalized collision energy: $35 \%$, capillary temperature: $200{ }^{\circ} \mathrm{C}$, and scan range: $m / z 300-2000$. The acquired MS/MS data were interpreted using the bioinformatics search engine Mascot version 2.1.0 (Matrix Sciences, London, UK). The peptide sequences were matched to the published sequences of coconut proteins from the National Center for Biotechnology Information (NCBI, Bethesda, MD, USA) database.

\subsection{Stability of the synthetic peptides}

Following the method of Tavares et al.,$^{31}$ peptide solutions were adjusted to $\mathrm{pH} 2.0$, mixed with pepsin $(E / S=1: 35)$ and incubated at $37{ }^{\circ} \mathrm{C}$ for $1 \mathrm{~h}$. Afterwards, the reaction mixture was adjusted to $\mathrm{pH} 7.0$, pancreatin was added $(1 \mathrm{~g} / 25 \mathrm{~g}$ peptide) and incubated at $37^{\circ} \mathrm{C}$ for $2 \mathrm{~h}$, and then the digestion was terminated by boiling for $10 \mathrm{~min}$. The ACE-inhibitory activity and -OH scavenging activity of the treated synthetic peptides and the untreated synthetic peptides were determined.

\subsection{Cell culture and cell viability determination}

The EA.hy926 cells were seeded in a 96-well plate at a density of $1.0 \times 10^{5}$ cells per $\mathrm{mL}$, cultured in DMEM (containing $1 \%$ nonessential amino acid solution, $10 \% \mathrm{FBS}, 100 \mathrm{IU} \mathrm{mL}^{-1}$ penicillin and $100 \mu \mathrm{g} \mathrm{mL} \mathrm{m}^{-1}$ streptomycin) in a humidified atmosphere of $5 \% \mathrm{CO}_{2}$ at $37^{\circ} \mathrm{C}$ for $24 \mathrm{~h}$. Then the wells were washed with phosphate buffer solution (PBS) and cultured in fresh DMEM but without FBS at $37^{\circ} \mathrm{C}$ for $12 \mathrm{~h}$. The DMEM without FBS was removed and the cells were cultured in DMEM at $37{ }^{\circ} \mathrm{C}$ for another $24 \mathrm{~h}$. Then the cells were treated with different sample concentrations (1.0, 1.5 and $2.0 \mathrm{mg} \mathrm{mL}^{-1}$ ) for $24 \mathrm{~h}$. Captopril $\left(1 \mathrm{mg} \mathrm{mL}{ }^{-1}\right)$ was used as the positive control, whereas the negative control was treated with only DMEM. Each treatment was repeated in six wells. After treatment, viability of the cells was measured using MTT method as described by Mosmann. ${ }^{32}$ Briefly, the cells were washed with PBS and $20 \mu \mathrm{L}$ of MTT $(5 \mathrm{mg}$ $\mathrm{mL}^{-1}$ ) were added into each well and kept at $37^{\circ} \mathrm{C}$ for $4 \mathrm{~h}$. Then MTT solution was removed and $100 \mu \mathrm{L}$ of dimethyl sulfoxide were added. The absorbance was measured at $490 \mathrm{~nm}$ by a Varioskan Flash (Thermo Scientific, USA).

\subsection{Effect on intracellular ET-1 content}

The EA.hy926 cells were seeded in a 96-well plate at a density of $1.0 \times 10^{5}$ cells per mL. After being cultured in the DMEM at $37^{\circ} \mathrm{C}$ for $24 \mathrm{~h}$, the cells were treated with different concentrations of test samples $\left(1.0,1.5\right.$ and $\left.2.0 \mathrm{mg} \mathrm{mL}^{-1}\right)$ for $48 \mathrm{~h}$. Captopril $\left(1 \mathrm{mg} \mathrm{mL}{ }^{-1}\right)$ was used as positive control and the negative control was treated with only DMEM. After treatment, the growth medium of each well was collected to quantify ET-1 content using the ET-1 Elisa kit following the manufacturer's instructions.

\subsection{Antioxidant activity of the peptides}

2.12.1. Protective effect against $\mathrm{H}_{2} \mathrm{O}_{2}$-induced cellular oxidative stress. The EA.hy926 cells were seeded in 96-well plates with $5 \times 10^{3}$ cells $\mathrm{mL}^{-1}$ and incubated at $37^{\circ} \mathrm{C}$ in $5 \% \mathrm{CO}_{2}$ for $24 \mathrm{~h}$. Then the cells were treated with various concentrations of test samples (1.0, 1.5 and $2.0 \mathrm{mg} \mathrm{mL}^{-1}$, dissolved in PBS) and incubated at $37^{\circ} \mathrm{C}$ for $24 \mathrm{~h}$, followed by treatment with $300 \mu \mathrm{M}$ $\mathrm{H}_{2} \mathrm{O}_{2}$ for another $24 \mathrm{~h}$. Cell viability was determined using the MTT method as described above. In the blank control, cells were treated only with the DMEM. In the $\mathrm{H}_{2} \mathrm{O}_{2}$ treated group (control group), cells were treated with $300 \mu \mathrm{M} \mathrm{H}_{2} \mathrm{O}_{2}$. In the sample group, cells were pretreated with different concentrations of samples then exposed to $300 \mu \mathrm{M} \mathrm{H}_{2} \mathrm{O}_{2} \cdot{ }^{4}$ The protective effect of samples against $\mathrm{H}_{2} \mathrm{O}_{2}$-induced cellular oxidative stress was calculated as follows:

$$
\text { Protective ability } \%=\left(A_{\mathrm{S}}-A_{\mathrm{C}}\right) /\left(A_{\mathrm{B}}-A_{\mathrm{C}}\right) \times 100
$$

where, $A_{\mathrm{S}}$ was the absorbance at $490 \mathrm{~nm}$ of the sample group, $A_{\mathrm{C}}$ was absorbance of the $\mathrm{H}_{2} \mathrm{O}_{2}$ treated group, and $A_{\mathrm{B}}$ was the absorbance of blank control.

2.12.2. Superoxide radical-scavenging activity. $100 \mu \mathrm{L}$ samples $\left(1 \mathrm{mg} \mathrm{mL}^{-1}\right)$ and $3 \mathrm{~mL}$ of pyrogallol solution $(3 \mathrm{mM})$ were mixed and the absorbance at $320 \mathrm{~nm}$ recorded at $30 \mathrm{~s}$ intervals using a spectrophotometer. The scavenging activity was determined as the percentage of inhibiting pyrogallol autoxidation, which was calculated from the absorbance at $320 \mathrm{~nm}$ in the presence or absence of samples. ${ }^{33} \mathrm{GSH}(1 \mathrm{mg}$ $\mathrm{mL}^{-1}$ ) was used as comparison.

2.12.3. Metal chelating capacity. According to the method of Jeong et al. ${ }^{34} 450 \mu \mathrm{L}$ of sample solutions $\left(100 \mu \mathrm{g} \mathrm{mL}^{-1}\right), 45 \mu \mathrm{L}$ of $2 \mathrm{mM} \mathrm{FeCl}_{2}$ and $1815 \mu \mathrm{L}$ of distilled water were mixed. The mixture was reacted with $90 \mu \mathrm{L}$ of $5 \mathrm{mM}$ ferrozine for $30 \mathrm{~min}$. Then the absorbance was read at $562 \mathrm{~nm}$. GSH $\left(100 \mu \mathrm{g} \mathrm{mL} \mathrm{m}^{-1}\right)$ was used as comparison and the chelating activity was calculated as follows:

$$
\text { Chelating activity }(\%)=\left[1-\left(A_{\mathrm{S}}-A_{\mathrm{B}}\right) / A_{\mathrm{C}}\right] \times 100
$$


where $A_{\mathrm{B}}$ was the absorbance of the blank, $A_{\mathrm{C}}$ was the absorbance of control (without the addition of ferrozine) and $A_{\mathrm{S}}$ was the absorbance of mixture contained samples.

\subsection{Statistical analysis}

All the experiments were repeated at least three times and mean values were used. Data were subjected to analysis of variance and Duncan value with a confidence interval of $95 \%$ was calculated to compare means.

\section{Results and discussion}

\subsection{ACE-inhibitory and antioxidant activity of CCAH}

Subjection to the high pressure treatment and the hydrolysis by the four enzymes, the DH of CCAH was $27.62 \% \pm 3.94 \%$, the ACE inhibition activity and $\cdot \mathrm{OH}$ scavenging ability were $48.34 \%$ $\pm 1.41 \%$ and $55.02 \% \pm 6.28 \%$, respectively. High pressure treatment was used to improve the $\mathrm{DH}$ and bioactivity of $\mathrm{CCAH}$, for it can increase the susceptibility of proteins to enzymatic action by exposing new cleavage sites that allow enzymes to reach otherwise buried hydrolysis sites, thereby increasing the $\mathrm{DH}$ of AACH and release more peptides with antioxidant and/or ACE-inhibitory activity. ${ }^{35}$

\subsection{Separation by ultrafiltration and Sephadex G-25 gel chromatography}

Among the three fractions from ultrafiltration, CCAH-III (MW < $3 \mathrm{kDa}$ ) exhibited a significantly higher ACE-inhibitory ability $\left(63.58 \pm 5.14 \%\right.$ at $\left.1 \mathrm{mg} \mathrm{mL}^{-1}\right)$ than those of CCAH-I $(41.64 \pm$ $3.94 \%)$ and CCAH-II ( $49.88 \pm 5.02 \%)$, which confirm the report that molecular weight (MW) makes a negative contribution to ACE-inhibitory activity of polypeptides. ${ }^{34}$ Through the Sephadex G-25 gel chromatography, CCAH-III was separated into three major fractions (Fig. 1a), of which the fraction A showed the highest ACE-inhibitory activity (74.29 $\pm 3.07 \%$, Fig. 1b) among the fractions, while it's $\cdot \mathrm{OH}$ scavenging activity $(53.01 \pm 4.29 \%)$ is lower than that of fraction $\mathrm{C}(68.27 \pm 2.05 \%)$. This meant that MW plays important role in the bioactivity of peptides, but it's not the risk factor. Peptides with high ACE-inhibitory don't always have high antioxidant activity at the same time. Both ACE-inhibitory activity and antioxidant ability were the evaluation indicators to separate and choose CCAH, while ACEinhibitory activity is the first factor. Hence the fraction A was chosen to further fractionation.

\subsection{Purification of the ACE-inhibitory and antioxidant peptides}

As shown in Fig. 1c, the fraction A was separated into six major fractions through the Sephadex G-15 gel chromatography, of which fraction A4 showed the highest ACE-inhibitory activity $(81.15 \% \pm 2.27 \%)$ and antioxidant capacity $(88.92 \% \pm 3.16 \%$, Fig. 1d). The fraction A4 was further isolated by RP-HPLC on a semi-preparative $\mathrm{C}_{18}$ column and nine major peaks named as A4a to A4i were obtained and collected (Fig. 1e). The fraction A4e with the highest ACE-inhibitory activity $(86.33 \pm 1.65 \%)$ and . OH scavenging capacity (92.79 $\pm 2.79 \%$, Fig. 1f) was further purified by RP-HPLC in an analytical $\mathrm{C}_{18}$ column $(\Phi 4.6 \mathrm{~mm} \times$ $250 \mathrm{~mm}$ ). As shown in Fig. 1g, A4e was separated into three fractions named A4e-1, A4e-2 and A4e-3. However, the ACEinhibitory and $\cdot \mathrm{OH}$ scavenging activity of A4e and $\mathrm{A} 4 \mathrm{e}-3$ have no significant differences $(P>0.05)$, and the bioactivities of A4e1 and A4e-2 were lower than those of A4e (Fig. 1h). This indicated that there may be synergistic effect among the fractions A4e-1, A4e-2 and A4e-3. ${ }^{25}$ The yield of fraction A4e and A4e-3 were $12.33 \mathrm{~g} / 100 \mathrm{~g}$ fraction A4 and $40.05 \mathrm{~g} / 100 \mathrm{~g}$ fraction A4e, respectively. The fraction A4e-3 showed the highest ACEinhibitory activity $(87.31 \% \pm 1.89 \%)$ and $\cdot \mathrm{OH}$ scavenging activity $(92.32 \% \pm 2.25 \%)$, then it was subjected to ESI-MS/MS analysis.

\subsection{Characterization of the purified peptides}

As shown in Table 2, three peptides Lys-Ala-Gln-Tyr-Pro-Tyr-Val (867.45 Da), Lys-Ile-Ile-Ile-Tyr-Asn (762.47 Da) and Lys-Ile-LeuIle-Tyr-Gly (705.44 Da) were identified in A4e-3. Their mass spectra by Nano-LC-ESI-Q-TOF MS/MS are shown in Fig. 2a-c. It was obvious that the identified peptides are all oligopeptides with 6 or 7 amino acid residues, corresponding to the report that the majority of ACE-inhibitory and/or antioxidant peptides are short sequences with 2-12 amino acids. ${ }^{3}$ Moreover, these peptides are all rich in hydrophobic and branched amino acids (Ile and Leu). Especially to KIIIYN and KILIYG, the content of branched amino acids (Ile and Leu) is reach to $50 \%$. More important, all these peptides have aromatic amino acid (Tyr) and branched-chain amino acids (Ile and Val) in the C-terminal tripeptide, and have Lys in the N-terminus. This may be attributed to the trypsin used during $\mathrm{CCAH}$ preparation which prefers to hydrolyze peptide bonds with Lys or Arg on the Cterminal end. ${ }^{18}$ Respect to KAQYPYV and KIIIYN, they have Val and Asn in the C-terminus, respectively.

In recent years, the correlation between structure and activity of various ACE-inhibitory peptides indicate that the C-terminal tripeptide residues play a predominant role in competitive binding to the active site of ACE, and peptides with a Pro and/or an aromatic residue (Trp, Tyr or Phe) and/or a branched aliphatic amino acid residue (Val, Ile, or Leu) in the C-terminal tripeptide always showed strong ACE-inhibitory effects., Activity data also suggests that the positive charge either on the guanidine group of C-terminal Arg or on the $\varepsilon$-amino group of $\mathrm{N}$-terminal Lys side chains contributes substantially to the inhibitory activity against ACE. ${ }^{4,27,36}$ Moreover, Rao et al. found that the Asn residue at the C-terminal of peptides (Ser-Leu-GlyAsn and Ile-Thr-Ala-Ser-Val-Asn) and Lys residue at the $\mathrm{N}$ terminal of peptides (Lys-Ile-Val-Ser-Asp and Lys-Val-Phe) also contributed to the ACE-inhibitory potency. ${ }^{37}$

Similarly, the structure-activity relationship of antioxidative peptides also demonstrated that the presence of aromatic, positively charged, and hydrophobic amino acid residues in the peptide are important in contributing to the radical-scavenging capacity of antioxidant peptides through donating hydrogen to reactive oxygen species. ${ }^{18}$ Moreover, the peptides with a Pro at Cterminal (like His-His-Pro and Pro-Asn-Arg-Pro-Gln-Phe) and the peptides with Val residues at either C-terminal or $\mathrm{N}$ - 
terminal (e.g. Val-Lys-Leu and Val-Lys-Val) could show strong . $\mathrm{OH}$ scavenging ability. ${ }^{\mathbf{1 0 , 3 1}}$ All the identified peptides in this paper are well fit for these structural features of ACE-inhibitory and antioxidant peptides. In addition, Zareia et al. have identified a peptide (Lys-Ile-Ile-Ile-Tyr) from palm kernel cake proteins, which had a similar amino acid sequence with the peptide Lys-Ile-Ile-Ile-Tyr-Asn obtained the current study. ${ }^{38}$ However, KIIIY demonstrated higher ACE-inhibitory ability $\left(\mathrm{IC}_{50}: 47.00 \pm 1.60 \mu \mathrm{M}\right)$ than that of KIIIYN $\left(\mathrm{IC}_{50}: 58.72 \mu \mathrm{M}\right)$ obtained in the current study. This proves once again that an aromatic amino acid residue in the C-terminal is very important to the ACE-inhibitory activity of peptides.
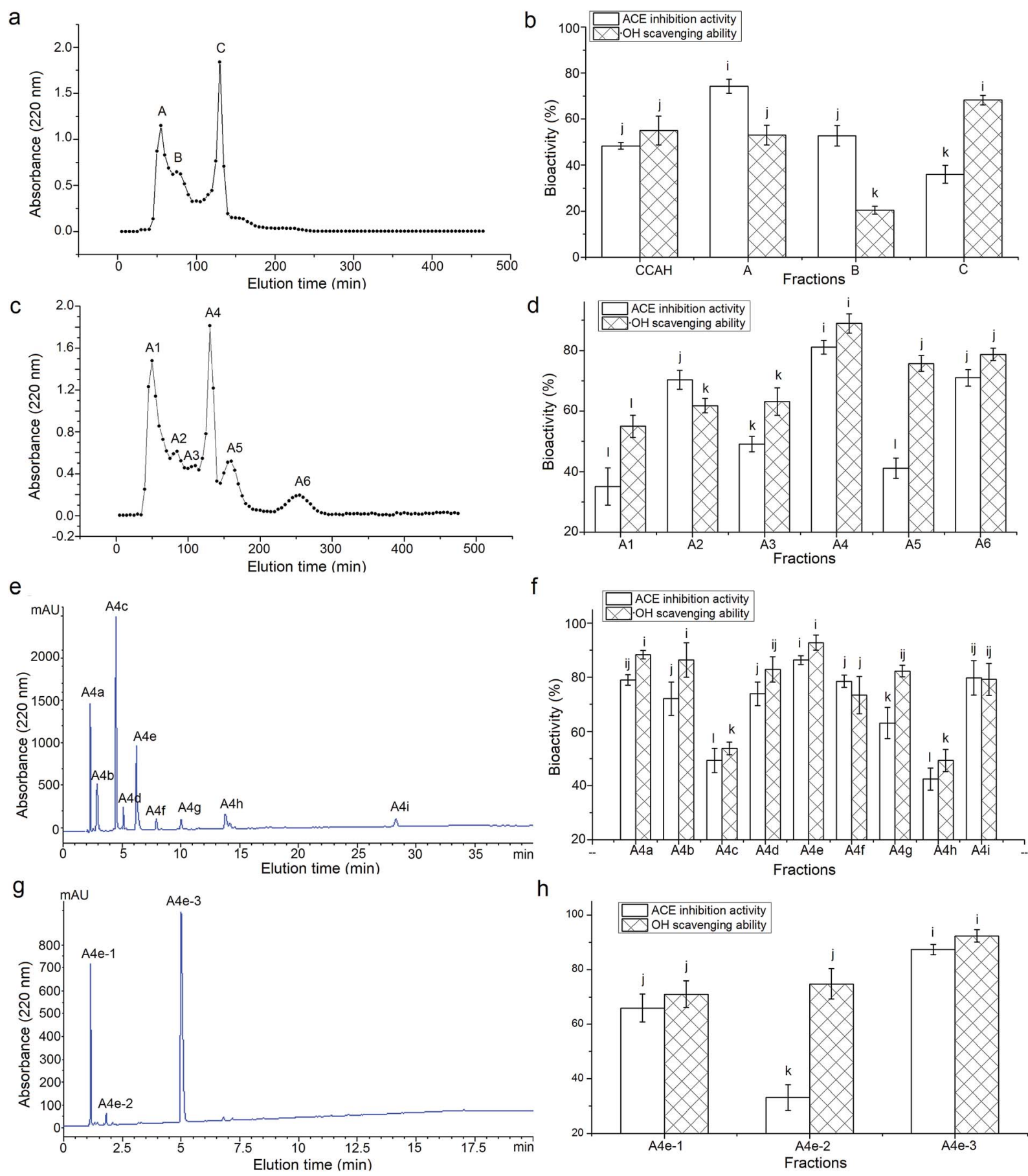

h

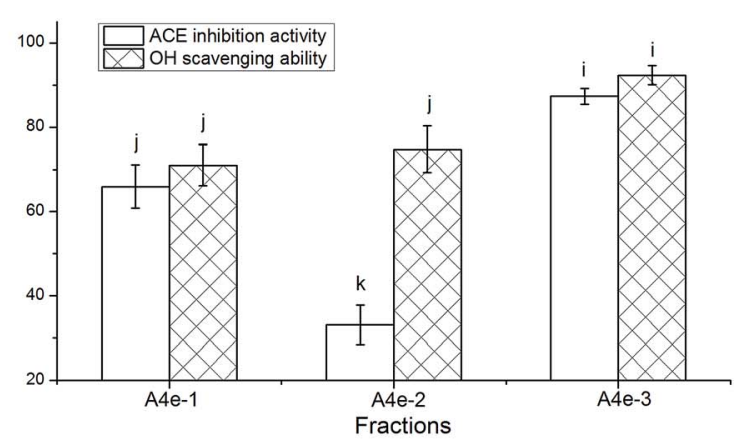

Fig. 1 Sephadex G-25 gel chromatography profile of CCAH-III (a) and ACE inhibition and · OH scavenging activity of each fraction (b); Sephadex G-15 gel chromatography profile of fraction A (c) and ACE inhibition and $\cdot \mathrm{OH}$ scavenging activity of each fraction (d); chromatography of fraction A4 separated by semi-preparing RP-HPLC with the linear gradient of acetonitrile $(5-30 \%$ in 30 min) containing $0.1 \%$ TFA at a flow rate of 2.5 $\mathrm{mL} \mathrm{min}^{-1}$ (e); and ACE inhibition and $\cdot \mathrm{OH}$ scavenging activity of each fraction (f); fraction A4e was isolated by analytical RP-HPLC at flow rate of 1 $\mathrm{mL} \mathrm{min}^{-1}$ with the linear gradient of acetonitrile $(15-30 \%$, in $15 \mathrm{~min})$ containing $0.1 \%$ TFA $(\mathrm{g})$; ACE inhibition and $\cdot \mathrm{OH}$ scavenging activities of fractions A4e-1, A4e-2 and A4e-3 (h). ${ }^{i-1}$ Different small letters on the bars with the same filled patterns mean significant difference $(P<0.05)$. 
Table 2 ACE-inhibitory and antioxidant peptides identified in coconut cake albumin by LC-MS/MS ${ }^{a}$

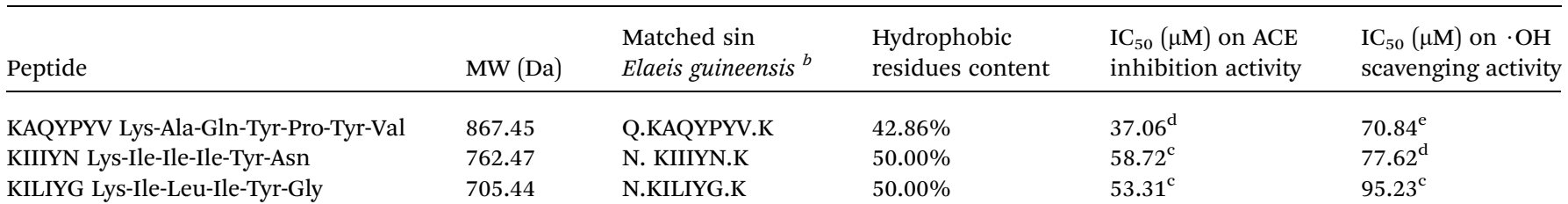

${ }^{a}$ Different small letters (c-e) in the same row means significant difference $(P<0.05) .{ }^{b}$ From National Center for Biotechnology Information (NCBI).

Though with a lager MW, KAQYPYV demonstrated the highest ACE-inhibitory activity $(37.06 \mu \mathrm{M})$ and antioxidant activity $\left(\mathrm{IC}_{50}\right.$ : $70.84 \mu \mathrm{M}$ ) among the three peptides, probably attributed to the presence of Tyr, Pro and Val residues at the C-terminal simultaneously. It has been demonstrated that ACE has four functional amino acid residues of Tyr, Arg, Glu and Lys at the active site and

\section{(a)}

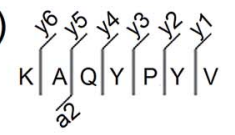

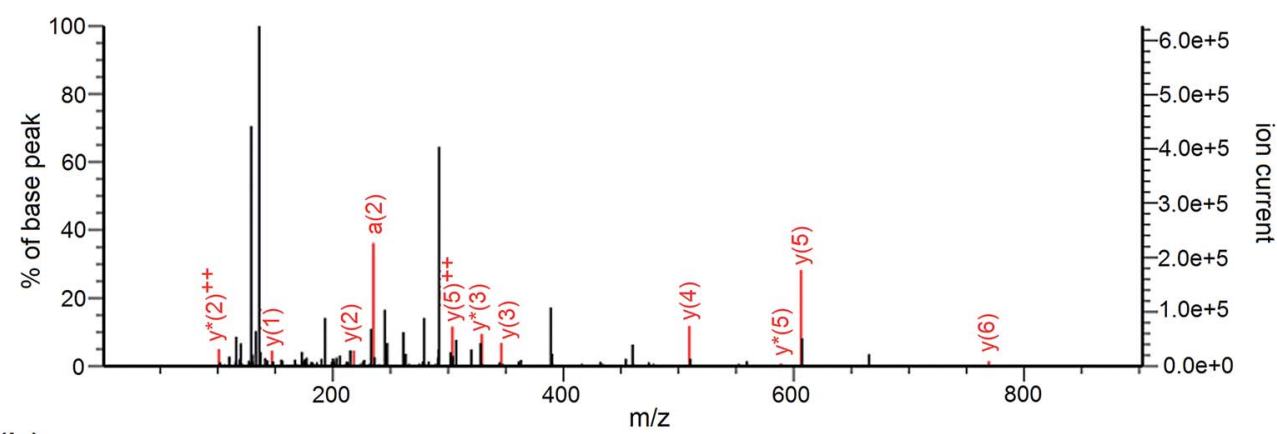

(b)

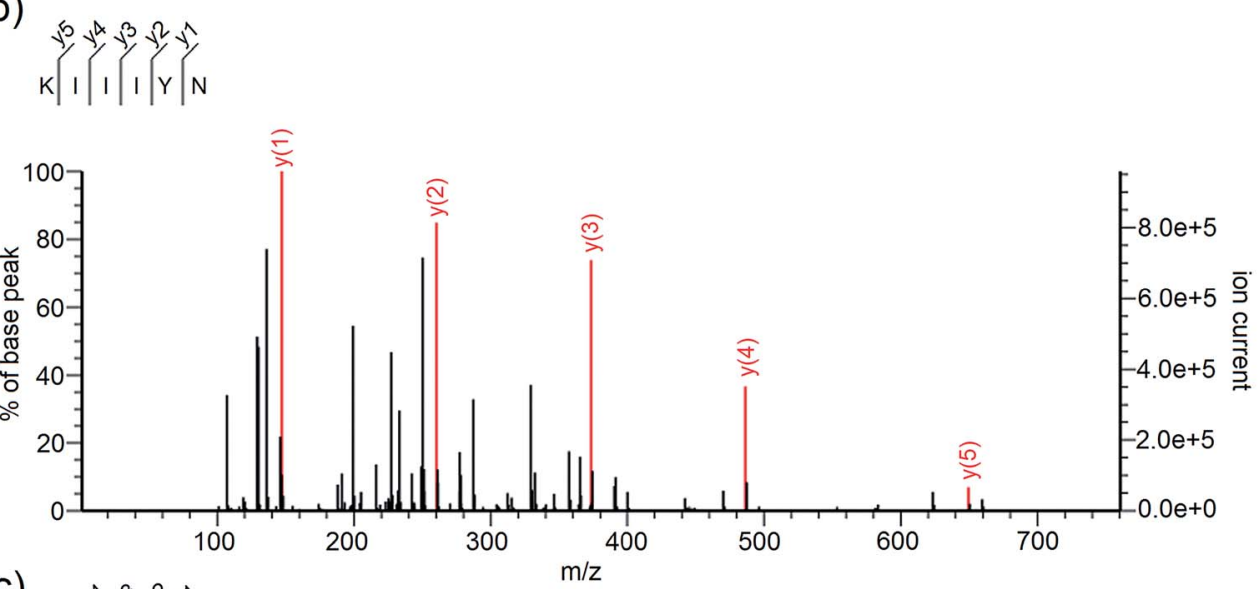

(c)
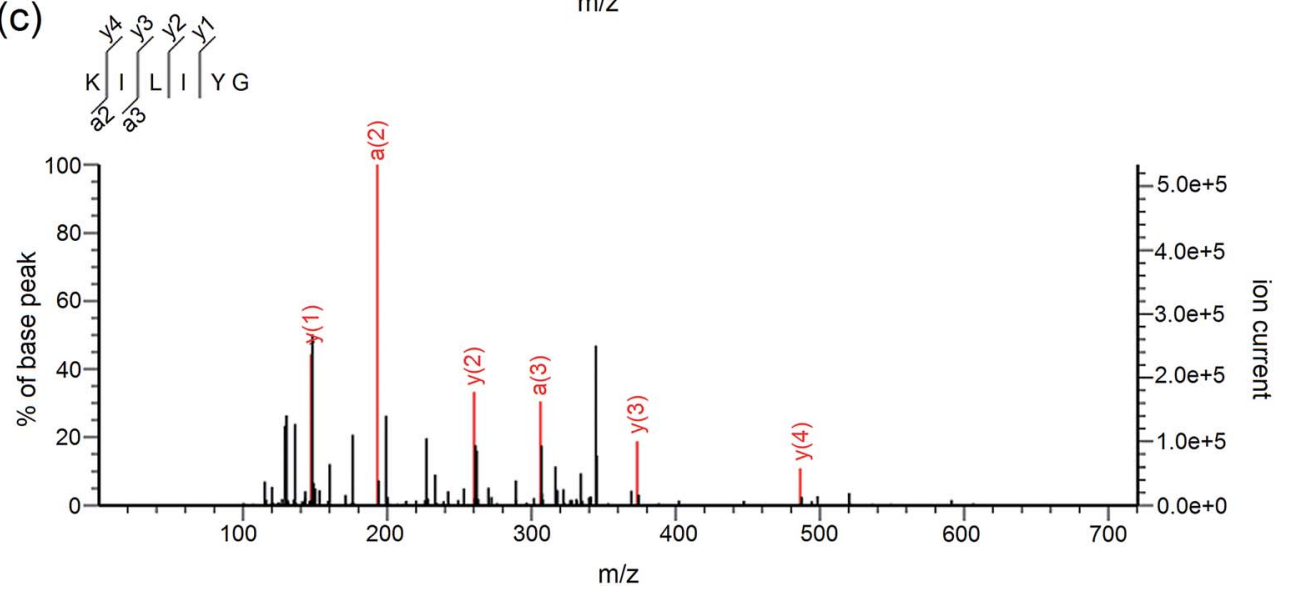

Fig. 2 Mass spectra of peptides KAQYPYV (a), KIIIYN (b) and KILIYG (c) identified by LC-MS/MS in coconut cake albumin hydrolysates (CCAH). 
three hydrophobic binding subsites, thus peptides with both aromatic residues (Tyr) and hydrophobic residues (Pro and Val) in the C-terminus have high affinity with these active sites. ${ }^{36}$

Furthermore, the $\mathrm{IC}_{50}$ values on ACE-inhibitory activity of the three peptides $(37.06$ to $58.72 \mu \mathrm{M})$ were lower than that of peptides identified from corn (Ala-Tyr, $\mathrm{IC}_{50}: 146.8 \mu \mathrm{M}$ ), egg white lysozyme (Ala-Met-Lys, $\mathrm{IC}_{50}: 94.2 \mu \mathrm{M}$ ) and sweet sorghum grain (Thr-Leu-Ser, $\left.\mathrm{IC}_{50}: 102.1 \mu \mathrm{M}\right) .{ }^{37,39,40}$ And the $\cdot \mathrm{OH}$ scavenging activity of the three peptides $\left(\mathrm{IC}_{50}: 70.84\right.$ to $\left.95.23 \mu \mathrm{M}\right)$ were also higher than that of peptides identified from tilapia skin gelatin (Leu-Ala-Arg-Leu, $\mathrm{IC}_{50}: 310.0 \mu \mathrm{M}$ ), salmon (Phe-LeuAsn-Glu-Phe-Leu-His-Val, $\mathrm{IC}_{50}: 152 \mu \mathrm{M}$ ) and bovine casein (FYYEQNL, IC $\left._{50}: 119.11 \mu \mathrm{M}\right) .^{7,18,41}$ This indicated that the peptides identified in the current study had a relatively high ACE-inhibitory and antioxidant activity.

\subsection{Stability and inhibition pattern of synthetic peptides}

The ACE-inhibitory and antioxidant peptides identified in $\mathrm{CCAH}$ were synthesized to confirm their activity and evaluate the stability against the gastrointestinal enzymes digestion. As shown in Fig. 3A, after digestion with pepsin followed by pancreatin, the $\mathrm{IC}_{50}$ values of KIIIYN and KILIYG decreased remarkably $(P<0.05)$. It was reported that pepsin preferentially cleaves the C-terminal to Phe, Leu and Glu, while pancreatin hydrolyses peptide bonds with aromatic side chains (Tyr, Trp and Phe) at N-terminal or C-terminal. ${ }^{18,42}$ The peptide KIIIYN can be split into KIIIY and $\mathrm{N}$ by pancreatin, while KILIYG can be split into KILIY and G. The bioactivity of split peptide KIIIY and KILIY with Tyr at C-terminal was expected to increase after digestion. In contrast, there was no significant decrease $(P>$ 0.05) in the ACE-inhibitory and antioxidant activity of the peptides KAQYPYV, suggesting that it could effectively retain the activity in the gastrointestinal digestion system. Although also with Tyr residue in C-terminals, KAQYPYV has a Pro in the C-terminus, which has a significant role in the stability of ACEinhibitory peptides against some proteases. ${ }^{36}$

ACE-inhibitory peptides were found to inhibit ACE via different inhibition modalities such as competitive, noncompetitive, uncompetitive and mixed inhibition manners. The kinetic constants of ACE in the presence of peptides KAQYPYV, KIIIYN and KILIYG revealed that, the $V_{\max }$ decreased but $K_{\mathrm{m}}$ changed differently (Fig. 3B-D), indicating a mixed modality of noncompetitive and uncompetitive inhibition. Similar peptides like EVSQGRP, SAAVGSP and VVLYK also exhibited mixed-mode inhibition patterns. ${ }^{11,27}$

\subsection{Effect on EA.hy926 cells proliferation and intracellular ET-1 content}

Result in Fig. 4A revealed that all the peptides (KAQYPYV, KIIIYN and KILIYG) showed no significant $(P>0.05)$ cytotoxicity
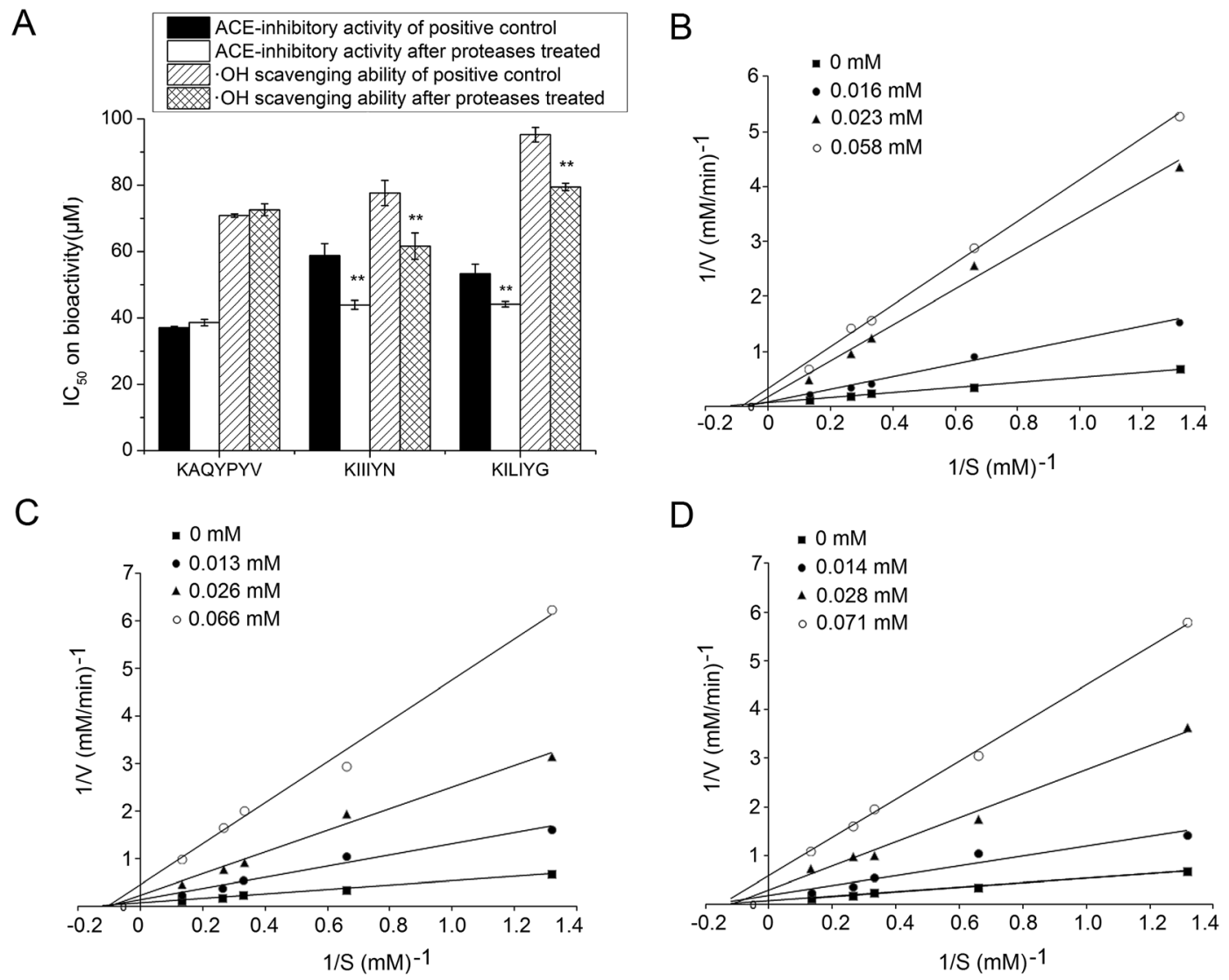

Fig. 3 Stability of synthetic peptides KAQYPYV, KIIIYN and KILIYG against the simulated gastrointestinal digestion (A), **on the bar meant significant difference compared to the positive control (untreated by proteases); and Lineweaver-Burk plot of the inhibitory effects on ACE of peptides KAQYPYV (B), KIIIYN (C) and KILIYG (D). 

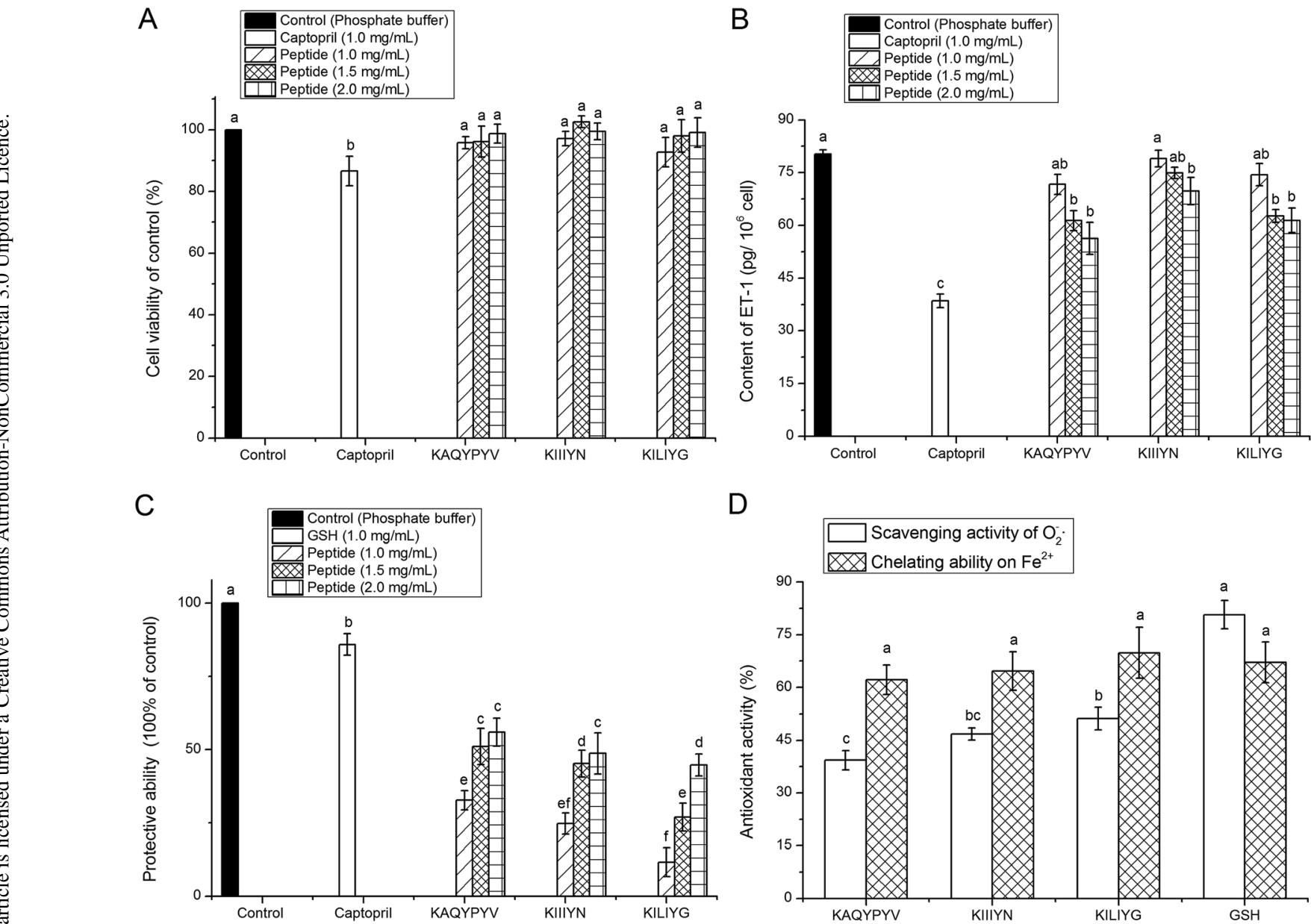

Fig. 4 Effect of peptides (KAQYPYV, KIIIYN and KILIYG) identified in CCAH on EA.hy926 cells' viability (A), intracellular endothelin-1 content (B), protection against damage induce by $\mathrm{H}_{2} \mathrm{O}_{2}(\mathrm{C})$, and superoxide radical scavenging activity and Fe ${ }^{2+}$ chelating ability (D). Captopril and glutathione (GSH) were used as the positive control, and small letters on the bars (a-f) mean significantly difference $(P<0.05)$

towards the EA.hy926 cells at the tested concentrations, meaning that these peptides are all safe material in terms of cellular toxicity and thereby could be used as a safe inhibitor of ACE and as effective antioxidant with no cytotoxicity to vascular endothelial cells. ${ }^{4}$

Other than the renin angiotensin system (RAS), the endothelin system has an increasingly recognized role in blood pressure regulation, in which ET-1 has powerful vasoconstrictor and pressor properties. Thus, peptides that can inhibit the intracellular ET-1 also have potential antihypertensive properties. ${ }^{5}$ Results in Fig. 4B showed that all the three peptides could effectively inhibit the intracellular ET-1 content with a concentration-dependent increase, indicating their potential antihypertensive effect, though which was lower than that of captopril $(P<0.05)$. Previous studies also demonstrated that ACEinhibitory peptides like Val-Phe-Tyr, Val-Val-Leu-Tyr-Lys and Val-Ile-Glu-Pro-Arg could play antihypertensive effects through inhibiting the expression of ET-1 in vascular endothelial cells. $^{27,43}$

\subsection{Antioxidant activity of the ACE-inhibitory peptides}

3.7.1. Protective effect against $\mathrm{H}_{2} \mathrm{O}_{2}$-induced cellular oxidative stress. $\mathrm{H}_{2} \mathrm{O}_{2}$ can trigger oxidative damage through the elevation of intracellular reactive oxygen species (ROS), which may activate the cell apoptosis pathway and eventually lead to a variety of diseases including cancer, diabetes mellitus, cardiovascular diseases, etc. ${ }^{18}$ As shown in Fig. 4C, all the peptides KAQYPYV, KIIIYN and KILIYG had significant protection effect on EA.hy926 cells against $\mathrm{H}_{2} \mathrm{O}_{2}$ induced damage (Fig. 4C), and an obvious dose-dependent relationship was observed among the low-, medium- and high-dose groups. The highest inhibition ability was found for peptide KAQYPYV at $2 \mathrm{mg} \mathrm{mL} \mathrm{m}^{-1}$, in accordance with its highest $\cdot \mathrm{OH}$ scavenging activity as shown in Table 2.

3.7.2. Superoxide radical-scavenging activity and $\mathbf{F e}^{2+}$ chelating ability. Among the three peptides, the KILIYG showed the highest superoxide radical scavenging activity though which is lower than GSH $(P<0.05)$, probably contributed to its high content of hydrophobic amino acid and lower MW (Fig. 4D). ${ }^{42}$ 
Moreover, the $\mathrm{O}_{2}{ }^{-\cdot}$ scavenging ability of KAQYPYV, KIIIYN and KILIYG were all higher than that of VLPPQQQY and VTSLDLPVLRW $\left(\mathrm{IC}_{50}: 661 \mu \mathrm{M}\right) .{ }^{44}$ Compared to $\mathrm{GSH}$, all the KAQYPYV, KIIIYN and KILIYG demonstrated a no significant different $(P>0.05) \mathrm{Fe}^{2+}$ chelating ability $(62.13-69.82 \%$ at $\left.0.1 \mathrm{mg} \mathrm{mL} \mathrm{m}^{-1}\right)$, which is much higher $(P<0.05)$ than that of peptides identified from sweet potato protein (YYIVS, $59.74 \%$ at $3 \mathrm{mg} \mathrm{mL}{ }^{-1}$ ) and tilapia gelatin (Leu-Ala-Arg-Leu, $46.53 \%$ at $\left.0.1 \mathrm{mg} \mathrm{mL}^{-1}\right) .{ }^{41,44}$

Both $\mathrm{O}_{2}{ }^{-\cdot}$ and $\cdot \mathrm{OH}$ are the most reactive among the oxygen radicals that can attract adjacent biomolecules, initiate oxidative chain reaction and induce the production of various radicals; and the presence of some metal ions like $\mathrm{Fe}^{2+}$ can extremely accelerate the oxidation reaction. ${ }^{42}$ In this point of view, the results in this paper demonstrated that the three peptides could exhibit high antioxidant activity via inhibiting the generation of radical or chelating $\mathrm{Fe}^{2+}$ or scavenging the radical produced during the oxidation reaction, and thereby protect vascular endothelial cells from oxidative damage. ${ }^{44}$

Furthermore, increasing studies demonstrated that ACEinhibitory peptides could play antihypertensive effect by one or more of the following ways: (1) inhibiting the ACE activity or improving activity of angiotensin-II converting enzyme (ACE2), (2) restraining the expression of ET-1 in vascular cells, (3) protecting vascular cells against oxidative damage, and (4) other ways. ${ }^{11,27,43}$ The results in the current study showed that the identified peptides in CCAH exhibited high ACE inhibition activity and antioxidant ability, and could effectively decrease the intracellular ET-1 and protect vascular cells against oxidative damage, indicating their potential antihypertensive effect.

\section{Conclusions}

Three novel ACE-inhibitory and antioxidant peptides comprised of 6-7 amino acids were identified in CCAH. The obtained peptides showed high ACE-inhibitory activity $\left(\mathrm{IC}_{50}: 37.06\right.$ to $58.72 \mu \mathrm{M}$ ), and high $\cdot \mathrm{OH}$ scavenging capacity ( $\mathrm{IC}_{50}: 70.84$ to 95.23 $\mu \mathrm{M}$ ), high $\mathrm{Fe}^{2+}$ chelating activity and considerable $\mathrm{O}_{2}{ }^{-\cdot}$ scavenging ability. Moreover, the three peptides could effectively reduce the intracellular ET-1 content and protect vascular endothelial cells from reactive oxygen species mediated damage, indicating their potential antihypertensive effect. Therefore, these peptides isolated from CCAH could be used as a functional food ingredient to control ACE activity and antioxidation.

\section{Conflicts of interest}

The authors declare that they have no competing interests.

\section{Acknowledgements}

This work was supported by the Key Research Project of Hainan Province (No. ZDYF2017061).

\section{References}

1 World Health Organization, Causes of death 2008: data sources and methods, World Health Organization, Geneva, 2010, available at http://www.who.int/healthinfo/ global_burden_disease/cod_2008_sources_methods.pdf.

2 L. Lin, S. Lv and B. F. Li, Angiotensin-I-converting enzyme (ACE)-inhibitory and antihypertensive properties of squid skin gelatin hydrolysates, Food Chem., 2012, 131, 225-230.

3 B. Hernández-Ledesma, M. M Contreras and I. Recio, Antihypertensive peptides: Production, bioavailability and incorporation into foods, Adv. Colloid Interface Sci., 2011, 165, 23-25.

4 S. W. A. Himaya, D. H. Ngo, B. Ryu and S. K. Kim, An active peptide purified from gastrointestinal enzyme hydrolysate of Pacific cod skin gelatin attenuates angiotensin-1 converting enzyme (ACE) activity and cellular oxidative stress, Food Chem., 2012, 132, 1872-1882.

5 S. M. Wallace, L. Yasmin, C. M. McEniery, M. Makj-Petaja, A. D. Booth, J. R. Cockcroft, L. B. Wilkinson, et al., Isolated systolic hypertension is characterized by increased aortic stiffness and endothelial dysfunction, Hypertension, 2007, 50, 228-233.

6 B. J. Bhuyan and G. Mugesh, Synthesis, characterization and antioxidant activity of angiotensin I converting enzyme inhibitors, Org. Biomol. Chem., 2011, 9, 1356-1365.

7 A. B. Shazly, Z. He, M. A. EI-Aziz, M. Zeng, S. Zhang, F. Qin and J. Chen, Fractionation and identification of novel antioxidant peptides from buffalo and bovine casein hydrolysates, Food Chem., 2017, 232, 753-762.

8 J. Ren, M. Zhao, J. Shi, J. Wang, Y. Jiang, C. Cui, Y. Kakuda and S. J. Xue, Purification and identification of antioxidant peptides from grass carp muscle hydrolysates by consecutive chromatography and electrospray ionizationmass spectrometry, Food Chem., 2008, 108, 727-736.

9 P. Behera, R. Kumar, I. V. R. Sandeep, R. Kapila, A. K. Dang and S. Kapila, Casein hydrolysates enhance osteoblast proliferation and differentiation in mouse bone marrow culture, Food Biosci., 2013, 2, 24-30.

10 L. Wattanasiritham, C. Theerakulkait, S. Wickramasekara, C. S. Maier and J. F. Stevens, Isolation and identification of antioxidant peptides from enzymatically hydrolyzed rice bran protein, Food Chem., 2016, 192, 156-162.

11 B. Forghani, M. Zarei, A. Ebrahimpour, R. Philip, J. Bakar, A. Abdul-Hamid and N. Saari, Purification and characterization of angiotensin converting enzymeinhibitory peptides derived from Stichopus horrens: Stability study against the ACE and inhibition kinetics, $J$. Funct. Foods, 2016, 20, 276-290.

$12 \mathrm{~S}$. Y. Lee and S. J. Hur, Antihypertensive peptides from animal products, marine organisms, and plants, Food Chem., 2017, 228, 506-517.

13 R. Z. Chiozzi, A. L. Capriotti, C. Cavaliere, G. L. Barbera, S. Piovesana and A. Laganà, Identification of three novel angiotensin-converting enzyme inhibitory peptides derived from cauliflower by-products by multidimensional liquid 
chromatography and bioinformatics, J. Funct. Foods, 2016, 27, 262-273.

14 R. Z. Chiozzi, A. L. Capriotti, C. Cavaliere, G. L. Barbera, S. Piovesana, R. Samperi and A. Laganà, Purification and identification of endogenous antioxidant and ACEinhibitory peptides from donkey milk by multidimensional liquid chromatography and nanoHPLC-high resolution mass spectrometry, Anal. Bioanal. Chem., 2016, 408, 56575666.

15 S. Piovesana, A. L. Capriotti, C. Cavaliere, G. L. Barbera, C. M. Montone, R. Z. Chiozzi and A. Laganà, Recent trends and analytical challenges in plant bioactive peptide separation, identification and validation, Anal. Bioanal. Chem., 2018, 410, 3425-3444.

16 C. M. Montone, A. L. Capriotti, C. Cavaliere, G. L. Barbera, S. Piovesana, R. Z. Chiozzi and A. Laganà, Peptidomic strategy for purification and identification of potential ACE-inhibitory and antioxidant peptides in Tetradesmus obliquus microalgae, Anal. Bioanal. Chem., 2018, 410, 3573-3586.

17 C. M. Montone, A. L. Capriotti, C. Cavaliere, G. L. Barbera, S. Piovesana, R. Z. Chiozzi and A. Laganà, Characterization of antioxidant and angiotensin-converting enzyme inhibitory peptides derived from cauliflower by-products by multidimensional liquid chromatography and bioinformatics, J. Funct. Foods, 2018, 44, 40-47.

18 A. Sila and A. Bougatef, Antioxidant peptides from marine by-products: Isolation, identification and application in food systems: A review, J. Funct. Foods, 2016, 21, 10-26.

19 U. Patil and S. Benjakul, Characteristics of albumin and globulin from coconut meat and their role in emulsion stability without and with proteolysis, Food Hydrocolloids, 2017, 69, 220-228.

20 Y. Li, Y. Zheng, Y. Zhang, J. Xu and G. Gao, Antioxidant Activity of Coconut (Cocos nucifera L.) Protein Fractions, Molecules, 2018, 23(3), 707.

21 M. J. Santana, A. L. D. Olivera, L. H. K. Q. Júnior, S. M. Mandal, C. O. Matos, R. D. Dias, O. L. Franco and L. M. Liao, Structural insights into Cn-AMP1, a short disulfide-free multifunctional peptide from green coconut water, FEBS Lett., 2015, 589, 639-644.

22 Y. Li, Y. Zheng, Y. L. Zhang, L. Y. Liu and S. L. Zhao, Purification, characterization, synthesis, in vivo and in vitro antihypertensive activity of bioactive peptides derived from coconut (Cocos nucifera L.) cake globulin hydrolysates, $R S C$ Adv., 2016, 6(95), 92688-92698.

23 Y. J. Zheng, Y. Li, Y. L. Zhang and S. L. Zhao, Purification, characterization and synthesis of antioxidant peptides from enzymatic hydrolysates of coconut (Cocos nucifera L.) cake protein isolates, $R S C$ Adv., 2016, 6, 54346-54356.

$24 \mathrm{FAO}$, production, http://faostat3.fao.org/browse/Q/*/E/, 2013, accessed 18 May, 2015.

25 M. Zhang, T. H. Mu and M. J. Sun, Purification and identification of antioxidant peptides from sweet potato protein hydrolysates by alcalase, Food Chem., 2014, 7, 191200.
26 K. Kwon, K. H. Park and K. C. Rhee, Fractionation and characterization of proteins from coconut (Cocos nucifera L.), J. Agric. Food Chem., 1996, 44(7), 1741-1745.

27 Y. J. Zheng, Y. Li, Y. L. Zhang, X. H. Ruan, Y. F. Zhang and S. L. Zhao, Purification, characterization, synthesis, in vivo ACE inhibition and in vitro antihypertensive activity of bioactive peptides derived from palm kernel expeller glutelin-2 hydrolysates, J. Funct. Foods, 2017, 28(2), 48-58.

$28 \mathrm{~J}$. Adler-Nissen, Determination of the degree of hydrolysis of food protein hydrolysates by trinitrobenzenesulfonic acid, $J$. Agric. Food Chem., 1979, 27, 1256-1262.

29 V. K. Jimsheena and L. R. Gowda, Colorimetric, highthroughput assay for screening angiotensin I-converting enzyme inhibitors, Anal. Chem., 2009, 81, 9388-9394.

30 K. Bush, P. R. Henry and D. S. Slusarchyk, Muraceinsmuramyl peptides produced by Norcardia orientalis as angiotensin converting enzyme inhibitors, J. Antibiot., 1984, 37, 330-335.

31 T. Tavares, M. D. Contreras, M. Amorim, M. Pintado, I. Recio and F. X. Malcata, Novel whey-derived peptides with inhibitory effect against angiotensin-converting enzyme: in vitro effect and stability to gastrointestinal enzymes, Peptides, 2011, 32, 1013-1019.

32 T. Mosmann, Rapid colorimetric assay for cellular growth and survival: application to proliferation and cytotoxicity assays, J. Immunol. Methods, 1983, 65, 55-63.

33 S. Marklund and G. Marklund, Involvement of the superoxide anion radical in the autoxidation of pyrogallal and a convenient assay for superoxide dismutase, Eur. J. Biochem., 1974, 47, 469-474.

34 J. B. Jeong, B. O. De Lumen and H. J. Jeong, Lunasin peptide purified from Solanum nigrum L. protects DNA from oxidative damage by suppressing the generation of hydroxyl radical via blocking fenton reaction, Cancer Lett., 2010, 293, 58-64.

35 M. J. Eisenmenger and J. I. Reyes-De-Corcuera, High pressure enhancement of enzymes: a review, Enzyme Microb. Technol., 2009, 45, 331-347.

36 A. Alemán, B. Giménez, E. Pérez-Santin, M. C. GómezGuillén and P. Montero, Contribution of Leu and Hyp residues to antioxidant and ACE-inhibitory activities of peptide sequences isolated from squid gelatin hydrolysate, Food Chem., 2011, 125, 334-341.

37 S. Rao, J. Sun, Y. Liu, H. Zeng, Y. Su and Y. Yang, ACE inhibitory peptides and antioxidant peptides derived from in vitro digestion hydrolysate of hen egg white lysozyme, Food Chem., 2012, 135, 1245-1252.

38 M. Zareia, B. Forghania, A. Ebrahimpoura, A. AbdulHamida, F. Anwarc and N. Saaria, In vitro and in vivo antihypertensive activity of palm kernel cake protein hydrolysates: sequencing and characterization of potent bioactive peptides, Ind. Crops Prod., 2015, 76, 112-120.

39 F. Lin, L. Chen, R. Liang, Z. Zhang, J. Wang, M. Cai and Y. Li, Pilot-scale production of low molecular weight peptides from corn wet milling byproducts and the antihypertensive effects in vivo and in vitro, Food Chem., 2011, 124, 801-807. 
40 Q. Wu, J. Du, J. Jia and C. Kuang, Production of ACE inhibitory peptides from sweet sorghum grain protein using alcalase: Hydrolysis kinetic, purification and molecular docking study, Food Chem., 2016, 199, 140-149.

41 Y. L. Zhuang and L. P. Sun, Preparation of reactive oxygen scavenging peptides from tilapia (Oreochromis niloticus) skin gelatin: optimization using response surface methodology, J. Food Sci., 2011, 76, C483-C489.

42 B. H. Sarmadi and A. Ismail, Antioxidative peptides from food proteins: a review, Peptides, 2010, 31, 1949-1956.
43 D. Liu, L. Zhang, S. Li, F. Liu and S. Z. Liang, Influence of angiotensin-converting enzyme inhibitory peptide on endothelial cell proliferation and endothelin expression in human umbilical vein cells, Chin. J. Clin. Rehabil., 2006, 10(25), 160-163.

44 E. Babini, D. Tagliazucchi, S. Martini, L. D. Più and A. Gianotti, LC-ESI-QTOF-MS identification of novel antioxidant peptides obtained by enzymatic and microbial hydrolysis of vegetable proteins, Food Chem., 2017, 228, 186-196. 